\title{
Migracja w świat online a realizacja założeń hipotezy kontaktu w dobie pandemii COVID-19
}

\begin{abstract}
Streszczenie
Współczesny, zglobalizowany świat wymaga od wielu osób nieustannego przemieszczania się pomiędzy obszarami nie tylko geograficznymi, ale również kulturowymi, a często funkcjonowania w wielu z nich równocześnie. Przedstawiciele różnych kręgów kulturowych, wyznaniowych, narodowych czy etnicznych spotykają się na co dzień w ramach procesu edukacji, realizacji zadań zawodowych lub spędzania czasu wolnego. Sprawne poruszanie się w takim środowisku wymaga wysoko rozwiniętych kompetencji międzykulturowych, a budowa tolerancyjnego społeczeństwa związana jest z przełamywaniem zakorzenionych w tradycji stereotypów i uprzedzeń.

Przez długi czas znaczny odsetek działań ukierunkowanych na nawiązywanie relacji i współpracy między osobami pochodzącymi z różnych kręgów kulturowych był oparty na założeniach hipotezy kontaktu, której istotą jest osobiste spotkanie, wymiana doświadczeń i weryfikacja przekonań. Takie podejście znajduje odzwierciedlenie m.in. w europejskich programach wspierania mobilności młodzieżowej i akademickiej, takich jak Erasmus+. Obecnie, w dobie ograniczenia możliwości przemieszczania spowodowanego pandemią wirusa SARS-CoV-2 większość aktywności w ramach systemów edukacji w całej Europie jest realizowana w formie zdalnej. Kontakt zapośredniczony przez nowe technologie bardzo często pozbawiony jest lub znacznie ogranicza możliwość odbioru niewerbalnych elementów komunikacji takich jak mimika twarzy, mowa ciała, proksemika
\end{abstract}

1 Dominika Zakrzewska-Olędzka, Instytut Psychologii, Akademia Pedagogiki Specjalnej im. Marii Grzegorzewskiej, Polska, e-mail: dzakrzewska@aps.edu.pl, ORCID ID: https://orcid.org/ 0000-0003-2744-7905. 
czy też czynniki paralingwistyczne.

Celem niniejszego artykułu jest podjęcie refleksji nad skutecznością działań opartych na hipotezie kontaktu w przypadku kontaktu na odległość oraz potrzebą poszukiwania nowych, alternatywnych rozwiązań w tym zakresie. Punktem wyjścia do niej jest analiza korzyści z realizacji działań opartych na kontakcie bezpośrednim, na przykładzie zaangażowania studentów programu Erasmus+ w działania z zakresu edukacji międzykulturowej w szkole podstawowej, a z drugiej strony trudności obserwowane w projektach międzynarodowych, w których kontakt między uczestnikami ze względu na wprowadzone ograniczenia musi być zapośredniczony przez media.

\section{Słowa kluczowe:}

hipoteza kontaktu, globalizacja, wielokulturowość, edukacja międzykulturowa, program Erasmus+, kontakt zapośredniczony przez nowe technologie

\section{Abstract}

The modern, globalized world require from many persons to be in constant movement between not only geographical areas but also cultural circles. Representatives of various cultural, religious, national or ethnic groups meet on a daily basis as part of the education process, professional tasks or free time. Efficient functioning in such an environment is not possible without extended intercultural competences and creating open and tolerant society goes along with the need of breaking, rooted in tradition, stereotypes and prejudices.

For a long time, a significant percentage of activities aimed at establishing relationships and cooperation between people from different cultures was based on the assumptions of the contact hypothesis, the essence of which is personal contact, exchange of experiences and verification of beliefs. This approach is reflected, inter alia, in in the European Erasmus + programs to support youth and academic mobility. Currently in the era of limitation of the possibility of movement caused by the SARS-CoV-2 coronavirus pandemic, most activities within education systems throughout Europe are carried out remotely. Contact mediated by new technologies very often lacks or significantly reduces the possibility of receiving non-verbal elements of communication, such as facial expressions, body language, proxemics or paralinguistic factors.

The purpose of this article is to reflect on the effectiveness of actions based on the contact hypothesis in the case of distance contact and the need to search for new, alternative solutions in this regard. The starting point will consist of analysis of the benefits from implementing activities based on direct contact, on the example of the involvement of Erasmus+ program students in activities in the field of intercultural education in primary school. 
On the other hand, the difficulties observed in international projects, in which contact between participants due to the introduced restrictions must be mediated by the media will be described.

\section{Keywords:}

contact hypothesis, globalization, multiculturalism, intercultural education, Erasmus + program, contact mediated by new technologies

\section{KONTEKST SPOLECZNO-KULTUROWY}

W czasach globalizacji kontakt z przedstawicielami innych kręgów kulturowych, wyznaniowych, narodowych czy etnicznych należy do codzienności milionów ludzi na całym świecie. Do momentu pojawienia się wirusa SARS-CoV-2 obserwowano stale wzrastającą mobilność społeczeństw. Przyczynił się do tego zarówno rozwój technologiczny, jak i liczne sojusze międzynarodowe, oferujące obywatelom państw członkowskich swobodne przemieszczanie się w obrębie ich terytoriów. Jednym z przykładów może być Unia Europejska, w której po zniesieniu kontroli granicznych nastąpiły znaczące wewnętrzne migracje ludności, motywowane chęcią zdobycia doświadczeń edukacyjnych, wolontariackich oraz zawodowych w innych krajach wspólnoty. Zgodnie z szacunkami Komisji Europejskiej nawet 4 miliony ludzi² wzięły udział w aktywnościach samego tylko sztandarowego programu mobilności akademickiej Erasmus+, obejmującego kształcenie i szkolenie zawodowe, mobilność pracowników, wolontariat i programy wymiany młodzieży, realizację studiów licencjackich, magisterskich i doktoranckich na zagranicznych uczelniach, partnerstwa strategiczne, sojusze na rzecz wiedzy i umiejętności sektorowych, a w obrębie każdego z nich szeroki wachlarz krótko- i długoterminowych projektów reprezentujących różnorodne obszary tematyczne. Mimo iż w dobie pandemii (szczególnie od końca pierwszego kwartału 2020 roku) wstrzymanych zostało wiele podróży zarówno prywatnych, jak i służbowych, charakteryzująca się w ostatnich latach wysokim tempem rozwoju mobilność w zakresie współpracy międzynarodowej nie została zawieszona, ale znacznie ograniczona.

Po początkowym okresie dezorientacji i przystosowywania się do nowych warunków zarówno placówki edukacyjne, jak i firmy komercyjne stopniowo wznowiły swoją działalność, również w wymiarze międzynarodowym. Nowe

${ }^{2}$ Komisja Europejska, Erasmus+, Najważniejsze dane liczbowe. https://ec.europa.eu/programmes/erasmus-plus/about/key-figures_pl [dostęp: 20.12.2020]. 
technologie umożliwiają kontynuację pracy w formie zdalnej, w zespołach, których członkowie znajdują się w różnych miejscach, pochodzą z różnych środowisk i współpracują ze sobą, będąc zakotwiczonymi w różnej czasoprzestrzeni. Osoby z całego świata wykonują zadania dla firm, organizacji pozarządowych czy agencji międzynarodowych prowadzących filie rozsiane po wszystkich kontynentach. Miejsce przebywania przestało w wielu wypadkach stanowić przesłankę kluczową przy aplikowaniu o pracę lub zatrudnianiu pracowników, jeżeli tylko dostępny jest odpowiedni sprzęt i stabilne połączenie z Internetem. Szkolenia i projekty w ramach wymian studenckich i wolontariatu organizowane są za pośrednictwem platform do komunikacji zdalnej, takich jak Skype, Zoom, MS Teams czy Google Classroom. Migracje, do tej pory odbywające się poprzez przemieszczenie się danej osoby do innego miejsca, ewoluowały w migracje zdalne, w ramach których pracownicy, studenci czy wolontariusze swoją zagraniczną aktywność realizują za pośrednictwem internetowych środków przekazu, nie zmieniając jednak fizycznego miejsca swojego pobytu. Ten trend wskazuje, że pomimo doświadczanych obecnie ograniczeń współpraca międzynarodowa i wzajemne zależności między krajami w dalszym ciągu będą się rozwijać.

Praca w zespole zawsze wiąże się z doświadczeniem różnorodności ze względu na cechy indywidualne każdej z osób, m.in. takie jak wiek, płeć, wykształcenie, cechy osobowości, przygotowanie zawodowe czy doświadczenia osobiste. W przypadku zespołu międzykulturowego należy dodatkowo wziąć pod uwagę specyfikę wynikającą z pochodzenia kulturowego, etnicznego, narodowego czy wyznaniowego. Niezależnie, czy praca w takiej grupie wykonywana jest zdalnie, czy w bezpośrednim kontakcie ze współpracownikami, wiąże się z szeregiem wyzwań, które znacząco wpływają na efektywność i tempo wykonywania zleconych zadań (Bartel-Radic, Lesca, 2014). Z większą łatwością odnajdują się w niej osoby, które miały okazję doświadczyć kontaktu z przedstawicielami innych kultur i dzięki temu ukształtować świadomość różnorodności kulturowej, etnicznej, wyznaniowej czy narodowej. To sprawia, że mogą z większą otwartością ustosunkować się do zwyczajów kultywowanych przez przedstawicieli innych kultur i traktować je jako zasób, a nie zagrożenie dla konstruktywnej współpracy. Dlatego też niezwykle ważne jest odpowiednie planowanie procesu edukacji, tak aby pozwalał na nabycie zarówno wiedzy teoretycznej, jak i rozwijanie kompetencji kluczowych (Chmielecka, 2019), do których należy m.in. świadomość i ekspresja kulturalna. 


\section{SPOLECZNE POTRZEBY I TRUDNOŚCI WDRAŻANIA EDUKACJI MIĘDZYKULTUROWEJ}

Wielokulturowość nie jest konstruktem jednolitym i łatwym do zdefiniowania. Jak pisze Nikitorowicz (2017, s. 14): „Wielokulturowość - rozumiana jako naturalny stan zróżnicowania, czyli współwystępowanie kultur w odróżnieniu od współistnienia w zgodzie z wypracowanymi zasadami - to wielość i naturalna różnorodność kultur na globie ziemskim, które wcześniej czy później »spotkają się« ze sobą za sprawą własną lub Innych”. W zależności od okoliczności historycznych i tła społecznego, wielokulturowość może przybierać różne, nie zawsze pozytywnie odbierane formy. Najczęściej spotykana w krajach Unii Europejskiej jest wielokulturowość oswojona, rozumiana i akceptowana (Lewowicki, 2015). Obejmuje ona historycznie zakorzenione grupy etniczne, narodowe, wyznaniowe czy kulturowe, których funkcjonowanie ujęte jest we współczesnych regulacjach prawnych (np. w zakresie prowadzenia szkół dwujęzycznych ${ }^{3}$ ). Przykładem obszarów dających możliwość doświadczenia zróżnicowania i odmienności są pogranicza, na których w przypadku Polski nawet jeśli koegzystencja różnych grup obarczona jest trudną pamięcią o bolesnych wydarzeniach z bardziej lub mniej odległej przeszłości, przez młodsze pokolenia kojarzona jest już w dużej mierze z wypracowanymi wspólnie dobrymi praktykami w zakresie koegzystencji. Bycie na pograniczu „nie dopuszcza do odrzucenia innych czy narzucania innym własnych poglądów, schematów. Uczy współistnienia, współpracy, życzliwości, otwartości, tym samym stwarza mniejsze przyzwolenie na nietolerancję i obojętność” (Nikitorowicz, 2014, s. 178). W innych warunkach wielokulturowość może jednak przybierać zupełnie inny obraz, kiedy dopiero jest oswajana, sztucznie narzucona lub traktowana instrumentalnie jako narzędzie manipulowania społeczeństwem. Może również przyjąć formę życia obok siebie grup, które odrzucają dialog, nie mają wspólnych celów i nie widzą wartości we współpracy i wzajemnym wspieraniu się w rozwoju. Niełatwo też zaakceptować wielokulturowość w sytuacji, kiedy związana jest z niesprawiedliwością społeczną i wyzyskiem, np. w ramach struktur społecznych zapewniających rdzennym mieszkańcom znacząco lepszy standard funkcjonowania niż imigrantom zarobkowym, nawet po wielu latach pobytu (Lewowicki, 2015), albo w warunkach, w których to nowi osadnicy osiągają pozycję dominującą, dążąc do wykorzenienia tradycji i zwyczajów rdzennych mieszkańców.

${ }^{3}$ W Polsce regulowane są przez Ustawę z dnia 6 stycznia 2005 r. o mniejszościach narodowych i etnicznych oraz o języku regionalny. http://isap.sejm.gov.pl/isap.nsf/download.xsp/ WDU20050170141/U/D20050141Lj.pdf [dostęp: 20.12.2020]. 
Z czasem w społeczeństwach charakteryzujących się współistnieniem różnych kultur „przechodzi się od reakcji na odmienność do interakcji, czyli celowego poznawania, zrozumienia, współpracy współdziałania, negocjacji, dialogu - kreuje się międzykulturowość” (Nikitorowicz 2012, s. 119), której perspektywa „oddaje i akcentuje transkulturowy charakter procesów wzajemnego uczenia się, włączenie w obszar własnych standardów i wartości kulturowych wartości innych grup, w sposób daleki od wymuszania asymilacji” (Korporowicz 1997, s. 69). Dlatego też w celu budowania społeczeństwa, w którym przedstawiciele różnych grup odnoszą się do siebie z szacunkiem i potrafią zaakceptować odmienność na rzecz współpracy w budowaniu wspólnej przyszłości, kluczowa jest edukacja międzykulturowa, rozumiana jako „refleksja teoretyczna i praktyka pedagogiczna związana z przygotowaniem jednostki w różnych fazach jej życia do funkcjonowania w warunkach zróżnicowania kulturowego" (Sobecki 2014, s. 109). Wśród czynników wspomagających nabywanie kompetencji międzykulturowych, definiowanych jako „zdolność do przyjęcia postawy relatywizmu kulturowego w kontaktach z przedstawicielami innych kultur" (Nikitorowicz 2009, s. 508), wymieniane są wiedza o innych kulturach, otwartość na doświadczenie i postrzeganie różnorodności jako zasobu, umiejętność uszanowania podobieństw i różnic kulturowych oraz ich świadome uwzględnienie w procesach komunikacji.

Z drugiej strony należy zwrócić uwagę na elementy zakłócające koegzystencję i współpracę między grupami. Należą do nich w szczególności uprzedzenia i stereotypy, zaburzające efektywną komunikację i nawiązywanie konstruktywnych relacji. Aby im przeciwdziałać, proponuje się szereg rozwiązań, wśród których należy wspomnieć klasyczną hipotezę kontaktu Allporta (1954). Zgodnie z jej założeniami wzajemne uprzedzenia między zantagonizowanymi grupami mogą zostać zniwelowane dzięki odpowiednio zaplanowanemu i koordynowanemu kontaktowi (Dąbrowa, Markowska-Manista, 2014), w którym zapewnione zostaną wspólny cel, dla którego osiągnięcia niezbędna jest współpraca wszystkich członków grupy, równość statusu spotykających się osób oraz aprobata autorytetów i osób znaczących. Jako czynniki zwiększające szansę sukcesu wymienia się dodatkowo obowiązywanie w grupie/ach społecznych norm równości, stworzenie przestrzeni do nawiązania nieformalnych, przyjacielskich relacji oraz powtarzalność pozytywnie odbieranego kontaktu w różnych sytuacjach społecznych, z wieloma przedstawicielami danej grupy. Aby jednak postulaty te mogły być zrealizowane, początkowym warunkiem jest udział przedstawicieli obu grup. Jeszcze do niedawna kontakt w kontekście hipotezy Allporta był rozumiany jako osobiste spotkanie. Jednak obecnie, w dobie epidemii, kiedy mobilność (szczególnie międzynarodowa i międzykontynentalna) stała się przedmiotem znacznych restrykcji, 
forma kontaktu polegająca na osobistym spotkaniu przynajmniej czasowo może nie być tak dostępna jak dotychczas.

Realizacja założeń hipotezy kontaktu międzykulturowego, a nawet samej edukacji międzykulturowej w monokulturowym społeczeństwie, w którym większość obywateli nie spotyka się na co dzień z przedstawicielami innych grup etnicznych, kulturowych, narodowych lub wyznaniowych, związana jest z licznymi trudnościami i wyzwaniami w różnych przestrzeniach wspólnego komunikowania (Markowska-Manista, 2016). Nawet jeżeli podejmowana jest realizacja projektów mających na celu zapoznanie z innymi kulturami, to rytuały wyekstrahowane poza kontekst funkcjonowania stają się pozbawione głębi, a często nawet sensu. Schematyczne opowiadanie o egzotycznych zwyczajach, tak innych od własnych przez osoby, które nigdy ich nie widziały ani nie doświadczyły, może nawet mieć mało wiarygodny wydźwięk i przez to zostać przyjęte bardziej jako wymysł nauczyciela niż rzeczywistość. Z tego powodu istotne jest umożliwienie bezpiecznego, zaplanowanego i moderowanego kontaktu z przedstawicielami prezentowanej kultury. Pełnią oni rolę ekspertów, którzy dzięki osobistemu doświadczeniu mogą nie tylko opowiedzieć o wybranych zwyczajach z perspektywy kulturowo-historycznej, ale też odnieść się do praktyki i zachodzących w niej przemian. Obecnie, kiedy działania edukacyjne w dużej mierze ograniczone są do komunikacji zapośredniczonej przez nowe technologie, można z łatwością zaprosić na lekcję osobę mieszkającą w dowolnym miejscu na świecie. Niestety spotkania realizowane w takiej formule pozbawione są większości elementów komunikacji niewerbalnej, które pozwalały na zrozumienie specyfiki innej kultury. Sposób organizacji spotkań online najczęściej pozwala na pokazanie przez kamerę wewnętrzną laptopa lub zewnętrzną podłączoną do komputera stacjonarnego jedynie twarzy rozmówcy, co eliminuje możliwość obserwowania mowy ciała, która podobnie jak proksemika jest równocześnie limitowana również przez konieczność siedzenia przy stole i pozostawania w obrębie zakresu kamery. Jeżeli jakość połączenia internetowego lub kamery jest słaba, albo też partner interakcji nie chce lub nie może z niej skorzystać, wówczas pozostaje jedynie kontakt głosowy. Zniekształcenia dźwięku podczas przesyłania utrudniają jednak wychwycenie czynników paralingistycznych, takich jak ton głosu czy intonacja.

Dzięki współpracy placówek edukacyjnych z innymi instytucjami i organizacjami działającymi w tej samej społeczności możliwe jest prowadzenie działań edukacyjnych z ukierunkowaniem na wyrównywanie braków społecznych. Do tego procesu nawiązuje termin „otwarcia kulturowego” (Januszewska, Markowska-Manista, 2017), który początkowo był używany w Europie Zachodniej w latach dziewięćdziesiątych dwudziestego wieku, w odniesieniu do procesu dostosowania 
usług oferowanych przez system opieki społecznej do potrzeb przybywających licznie imigrantów zarobkowych. Od tego czasu, wraz ze stałym napływem ludności o odmiennym kontekście kulturowym, wdrażanie tego podejścia rozpowszechniło się również wśród organizacji pozarządowych, instytucji publicznych i ośrodków edukacyjnych. Koncepcja otwarcia kulturowego miała zagwarantować, że wszyscy członkowie danego społeczeństwa, niezależnie od ich przynależności kulturowej, będą mieli równe możliwości uczestnictwa we wszystkich sferach życia społecznego i równy dostęp do usług (społecznych, edukacyjnych i zdrowotnych) zapewnianych przez państwo. Podejście to jest zorientowane na integrację i przeciwdziałanie wykluczeniu społecznemu. Jest realizowane poprzez wykorzystanie wszystkich dostępnych zasobów w określonym społeczeństwie i uznanie potencjału kulturowego migrantów.

W odniesieniu do praktyki szkolnej i działań edukacyjnych otwarcie międzykulturowe dotyczy aspektu przygotowania kadry kierowniczej szkół, nauczycieli, specjalistów i personelu pomocniczego placówek oświatowych do pracy z grupą zróżnicowaną kulturowo, z poszanowaniem praw i potrzeb uczniów z kontekstem kulturowym innym niż grupa dominująca w danym społeczeństwie (Markowska-Manista, 2019). Może obejmować również podejmowanie współpracy z instytucjami, organizacjami pozarządowymi czy grupami aktywistów, działającymi w danym środowisku lokalnym, w celu efektywnej realizacji edukacji międzykulturowej. W zależności od celu podjęcia danego partnerstwa oraz poziomu edukacji, którego ono dotyczy, może być realizowane na wiele sposobów, m.in. jako spotkania, warsztaty, publikacje, akcje wolontariackie. Tego rodzaju inicjatywy są też okazją do rozwijania świadomości i aktywności obywatelskiej młodych ludzi poprzez zapoznanie ich z zasobami środowiska lokalnego i praktykę wspólnego działania dla obopólnych korzyści.

\section{WSPÓŁPRACA W RAMACH PROGRAMU ERASMUS+ JAKO MOŻLIWOŚĆ WPROWADZENIA ASPEKTU MIĘDZYKULTUROWEGO DO ŚRODOWISKA SZKOLNEGO}

Program Erasmus został zainicjowany przez Unię Europejską w roku 1987, w celu zacieśniania współpracy między krajami wspólnoty europejskiej oraz umożliwienia jej obywatelom (w szczególności uczniom, studentom, nauczycielom i pracownikom uczelni wyższych) poszerzenia wiedzy i zdobycia kompetencji międzykulturowych. W procesie integrowania wspólnoty europejskiej, do której miały należeć społeczeństwa o różnych tradycjach, kulturze, religii oraz strukturze etnicznej, 
szczególne znaczenie przypisywano edukacji międzykulturowej, służącej przygotowaniu dzieci i młodzieży do codziennego funkcjonowania w zróżnicowanym społeczeństwie. Polska uczestniczy w programie Erasmus od 1998 roku, najpierw jako kraj spoza UE, a od 2004 r. jako państwo członkowskie (Sasin, 2014). Sposobu na osiągnięcie celów programu upatrywano w nawiązywaniu bezpośredniego kontaktu, co umożliwiały krótko- i długoterminowe mobilności, po zakończeniu których ich stypendyści, bogatsi o nową wiedzę i doświadczenie, wracali do swoich krajów pochodzenia. Podczas pobytu zagranicznego uczestnicy nawiązywali kontakty, które następnie miały pomóc im w rozwoju osobistym, akademickim czy zawodowym. W wyniku obostrzeń związanych ze stanem epidemii możliwość odbycia mobilności w ramach programu Erasmus+ została znacznie ograniczona. Można przypuszczać, że jeżeli stan ten będzie utrzymywał się w kolejnych miesiącach, zostaną podjęte działania mające na celu dostosowanie warunków realizacji programu do obowiązujących możliwości i utrudnień. Trudno jednak przewidzieć na tym etapie rozważania zmian, czy kontakt pobawiony możliwości osobistego spotkania (a często nawet szansy na zobaczenie lub usłyszenie drugiej osoby) pozwoli na osiągnięcie chociaż częściowo takich efektów jak dotychczasowa strategia, czy i w jakim zakresie założenia hipotezy kontaktu będą działały również w przypadku kontaktu zdalnego, i jakie musiałyby zostać spełnione warunki, aby tak się stało.

Polska jest krajem o wysokim poziomie homogeniczności kulturowej i etnicznej, charakteryzującym się relatywnie niskim procentem przedstawicieli mniejszości narodowych i etnicznych oraz cudzoziemców w populacji ogólnej. Wyniki ostatniego Narodowego Spisu Powszechnego Ludności i Mieszkań (2011) wskazują, że „ludność o jednorodnej polskiej tożsamości narodowej” stanowiła 94,8\% (s. 89). Taka struktura społeczna sprawia, że dla wielu uczniów, szczególnie na wczesnych etapach edukacji, osobiste doświadczenie kontaktu międzykulturowego nie jest kwestią tak oczywistą, jak dla ich rówieśników w krajach Europy Zachodniej. Przykładem projektu zrealizowanego dzięki mobilnościom akademickim studentów w ramach programu Erasmus+ była współpraca nawiązana pomiędzy Katedrą UNESCO im. Janusza Korczaka Interdyscyplinarnych Studiów nad Rozwojem i Dobrostanem Dziecka w Akademii Pedagogiki Specjalnej im. Marii Grzegorzewskiej w Warszawie (więcej: Zakrzewska-Olędzka, Markowska-Manista, 2019) a lokalną szkołą podstawową w Warszawskiej dzielnicy Ochota, zainspirowana koncepcją otwarcia kulturowego. W ramach wspólnych działań przeprowadzony został projekt warsztatów międzykulturowych, przygotowanych we współpracy ze studentami kierunków pedagogika i psychologia, przebywającymi w Polsce w ramach wymiany akademickiej Erasmus+. W działaniach zreali- 
zowanych w latach 2017-2019 wzięło udział 39 studentów programu Erasmus+, z których każdy przebywał w Polsce jeden semestr. Reprezentowali oni takie kraje, jak: Grecja, Hiszpania, Portugalia, Niemcy, Słowenia oraz Republika Czeska. Ideą projektu było przeprowadzenie spotkań o charakterze partycypacyjnym, w formule opartej na założeniach hipotezy kontaktu, które przyniosłyby wielowymiarowe korzyści wszystkim ich uczestnikom.

Początkowo studenci mieli możliwość odwiedzenia szkoły podstawowej, we współpracy z którą realizowany był projekt, zapoznania się z zasadami funkcjonowania placówki oraz poznania klas, dla których miały być przygotowane warsztaty. Podczas pierwszego, warsztatowego spotkania z uczniami studenci przeprowadzali miniwywiady ukierunkowane na identyfikację zainteresowań klas, a następnie pod opieką wykładowcy prowadzącego przygotowywali w zespołach scenariusze warsztatów międzykulturowych, które następnie omawiali z innymi grupami studenckimi. Kolejnym etapem było skonsultowanie scenariuszy z pedagogiem i psychologiem szkolnym i wprowadzenie sugerowanych modyfikacji. Następnie studenci przeprowadzali warsztaty w wybranych klasach. Po każdej z lekcji otrzymywali informację zwrotną odnośnie do poprowadzonych zajęć od wychowawcy klasy, pedagoga szkolnego, wykładowcy oraz uczestników. Po zebraniu informacji zwrotnych każda z grup miała możliwość modyfikacji scenariusza zajęć i przeprowadzenia ich ponownie w innej klasie z tego samego poziomu nauczania. Warsztaty prowadzone były w języku angielskim i dotyczyły tematyki związanej z kulturą kraju pochodzenia studentów. Ze strony szkoły w projekcie brali udział nauczyciele, pedagog i psycholog szkolny oraz uczniowie. Warsztaty międzykulturowe prowadzone były dla uczniów z klas 3-5, w sumie dla 24 klas. Ze względu na konieczność wsparcia językowego zaangażowano również uczniów z klas 7-8 będących członkami szkolnego klubu wolontariatu (dwie klasy 7 i dwie klasy 8), co dało im możliwość szlifowania kompetencji językowych w zakresie języka angielskiego oraz kształtowania postaw prospołecznych i poczucia odpowiedzialności za społeczność szkolną.

Po każdym cyklu realizacji warsztatów przeprowadzane były spotkania podsumowujące z kadrą placówki. Wśród korzyści z udziału w projekcie dla społeczności szkolnej wymienionych w trakcie ewaluacji projektu przez nauczycieli, pedagoga i psychologa szkolnego znalazły się: zaangażowanie uczniów w działania międzykulturowe oraz wprowadzenie elementów edukacji międzykulturowej w atrakcyjny, interesujący sposób; inspiracja nauczycieli odnośnie do aktywnych metod pracy z grupą oraz nauczania z wykorzystaniem nowych technologii; kształtowanie pozytywnego stosunku do przedstawicieli innych grup narodowych i kulturowych; zwiększenie motywacji do nauki języków obcych wśród młodszych uczniów 
oraz nabycie pewności siebie w posługiwaniu się językiem angielskim wśród uczniów starszych klas; kształtowanie poczucia odpowiedzialności wśród starszych uczniów, którzy pełnili rolę asystentów i tłumaczy podczas wizyty gości w szkole.

Również studenci biorący udział w projekcie opisali szereg pozytywnych aspektów, takich jak: możliwość realizacji zajęć praktycznych i zdobycia doświadczenia w pracy z grupą o innych kontekście kulturowym od własnego; uzyskanie informacji zwrotnej, zgodnej z modelem 360 stopni, w ramach której otrzymali sugestie od wykładowcy prowadzącego projekt, pedagoga i psychologa szkolnego, wychowawcy klasy, uczniów biorących udział w zajęciach jako uczestnicy i jako asystenci oraz od członków swojej grupy; zapoznanie się z polskim systemem edukacji, sposobem prowadzenia zajęć lekcyjnych, organizacją szkoły i wykorzystywanymi metodami dydaktycznymi; rozwijanie kompetencji językowych w zakresie języka angielskiego; podnoszenie poziomu pewności siebie.

Spotkania zaaranżowane w ramach realizowanego projektu ze względu na ograniczenia logistyczne pozwoliły na wypełnienie jedynie niektórych założeń hipotezy kontaktu. Mimo to pozytywne rezultaty podjętych działań na wielu płaszczyznach zostały dostrzeżone przez wszystkich uczestników projektu i wszyscy wyrażali chęć kontynuowania rozpoczętej inicjatywy w przyszłości. Niestety w związku z ograniczeniem mobilności akademickich w wyniku epidemii COVID-19 działania w ramach nawiązanej współpracy zostały czasowo zawieszone.

\section{REFLEKSJE KOŃCOWE}

Przez długi czas zdobywanie kompetencji międzykulturowych kojarzone było z działaniami opartymi na hipotezie kontaktu, w której kluczową rolę odgrywa bezpośrednie spotkanie przedstawicieli różnych grup kulturowych, wyznaniowych, narodowych czy etnicznych. Dzięki wzajemnemu poznaniu i zrozumieniu, które osiągano w wyniku wzajemnych interakcji, możliwe było w wielu przypadkach znaczne zredukowanie wzajemnych uprzedzeń i stereotypów. Współcześnie, w miarę postępującego rozwoju nowych technologii, coraz więcej aktywności człowieka przenosi się do cyberprzestrzeni. We wszystkich kategoriach wiekowych podnosi się poziom wykorzystania internetowych narzędzi informacyjno-komunikacyjnych (Sarzała i Piestrzyński, 2015) w każdej sferze życia prywatnego i zawodowego człowieka. Jak wskazuje World Bank (Digital Dividends Report, 2016), wdrażanie nowych technologii stanowi kluczowy element dla umożliwienia rozwoju gospodarczego państw, a co za tym idzie, dla podnoszenia poziomu życia obywateli. Internet, powiązane z nim aplikacje czy oprogramowanie wy- 
korzystywane do pracy na urządzeniach elektronicznych znajdują zastosowanie w podtrzymywaniu relacji towarzyskich i rodzinnych, nauki, rozrywki, robienia zakupów czy wykonywania pracy. Cyfryzacja nie omija nawet środowiska szkolnego, w którym coraz powszechniej stosuje się oprogramowanie umożliwiające zdalny kontakt między kadrą szkoły a uczniami i rodzicami oraz bieżące monitorowanie osiągnięć szkolnych i przekazywanie informacji. Popularność zyskuje również e-learning, pozwalający na zdobywanie wiedzy bez konieczności fizycznej obecności w sali wykładowej, w niektórych formach niewymagający też obecności nauczyciela prowadzącego, co umożliwia dostosowanie czasu i tempa nauki do potrzeb i dyspozycji czasowych osoby uczącej się.

Rok 2020 przyniósł szczególne zmiany w funkcjonowaniu całego systemu edukacji, poprzez wymuszone epidemią okrojenie do minimum kontaktów społecznych, które znacznie przyspieszyło wdrażanie technik prowadzenia zajęć zdalnie. Przez szereg tygodni dzieci i młodzież były zmuszone do pozostawania w domu, bez możliwości bezpośredniego kontaktu nawet z najbliższym kręgiem znajomych, kolegów i koleżanek z klasy szkolnej lub grupy przedszkolnej oraz ze starszymi członkami rodziny, głównie dziadkami (Markowska-Manista, Zakrzewska-Olędzka, 2020). Rodziny doświadczyły też wielu utrudnień w codziennym funkcjonowaniu zawodowym i edukacyjnym całej rodziny w formie zapośredniczonej przez nowe technologie. Należały do nich przede wszystkim niewystarczająca liczba narzędzi (komputerów, laptopów, tabletów), słabej jakości łącza internetowe oraz trudności w łączeniu pracy zdalnej z pomocą dzieciom w nauce zdalnej i zajmowaniu się domem. Zwracano też uwagę na trudności w planowaniu dnia i utrzymaniu odpowiedniego poziomu motywacji do wykonywanych zadań, kiedy wszystkie one realizowane były z domu. Nauka zdalna, zarządzona - choć w różnym wymiarze - we wszystkich krajach UE, początkowo spowodowała zmiany, a następnie w dużej mierze zawieszenie realizacji programów promujących mobilność akademicką. Wprowadzone obostrzenia wpłynęły na możliwość kontynuowania wielu projektów skierowanych do społeczności lokalnych, w których udział brała młodzież uczestnicząca w programach mobilności europejskich (m.in. Erasmus+).

W zamian pojawiają się projekty realizowane zdalnie, opierające się na kontakcie zapośredniczonym przez media. Aspekt komunikacji na odległość, do tej pory rozpatrywany głównie jako sposób podtrzymania znajomości między osobami mieszkającymi w znacznej odległości lub też możliwość nawiązania kontaktu z mieszkańcami odległych miejsc (Mesch 2020) z dnia na dzień stał się podstawowym sposobem komunikacji na wszystkich płaszczyznach życia rodzinnego, zawodowego czy edukacyjnego. Zastąpienie relacji osobistych, twarzą w twarz, przez kontakt z wykorzystaniem nowych technologii wydaje się zubażające dla 
ich trwałości i jakości. Badania wskazują jednak, że dzieje się tak tylko w początkowym etapie, a kontakt na odległość kontynuowany przez dłuższy czas może zbliżyć dwie osoby równie mocno jak spotkania na żywo (Mesch, Talmud 2007; Chan, Cheng 2004). Wyklucza jednak w znacznym stopniu korzystanie z sygnałów niewerbalnych, mowy ciała i mimiki twarzy, które są kluczowe do prawidłowego rozumienia drugiej osoby.

Z obserwacji bezpośredniej procesu zdalnej realizacji w roku 2020 projektu międzynarodowego z udziałem studentów (Future Cooperation in Digital Education), którego celem było m.in. nawiązanie relacji w kontekście międzykulturowym, wynika, że w sytuacji, kiedy kontakt bezpośredni musi z różnych względów zostać zastąpiony komunikacją zapośredniczoną przez media, dużo większą uwagę i więcej czasu należy poświęcić na fazę integracji uczestników (obserwacje własne). Fakt zapośredniczenia kontaktu przez media sprawił, że uczestnikom projektu dużo łatwiej było w sytuacjach trudnych lub wieloznacznych wycofać się z kontaktu i uniknąć zaangażowania w rozwiązanie nieporozumień w grupie. Kontakt wirtualny pozwalał też na utrzymanie mniejszego zaangażowania emocjonalnego, a co za tym idzie, mniejszego poczucia zobowiązania wobec innych osób w grupie, przez co realizowane zadania nie stanowiły priorytetu. Fakt fizycznej odległości eliminował też możliwość interakcji nieformalnych i nawiązania przyjacielskich relacji, które naturalnie wystąpiłyby np. podczas przerw lub w trakcie wspólnych posiłków. Przydatne okazują się w takiej sytuacji komunikatory internetowe (np. Whatsapp, Messenger) pozwalające na utworzenie czatu grupowego. Po dołączeniu do niego osoby koordynującej pracę danego zespołu można w sprawny sposób monitorować postępy i zauważyć spadki aktywności poszczególnych uczestników oraz zachęcać ich do dzielenia się elementami związanymi z codziennym funkcjonowaniem (np. przygotowaniami do świąt i tradycjami w danym regionie/kraju).

Kolejną niezwykle istotną kwestią wydaje się bardzo precyzyjne formułowanie oczekiwań i terminów realizacji zadań oraz sposobu działania w różnych sytuacjach. Z rozmów przeprowadzonych uczestnikami tego rodzaju projektów w ostatnich miesiącach (wrzesień-grudzień 2020) wynikało, że jeżeli jakieś polecenie nie było dla nich jasne, to raczej czekali na zainteresowanie kadry brakiem postępów w realizacji zadania, niż wykazywali inicjatywę, aby poprosić o wyjaśnienie wątpliwości. Również z powodu braku bezpośredniego kontaktu weryfikacja realizowanych zadań była utrudniona, a uczestnicy tracili poczucie upływającego czasu, przez co wszystkie zadania znacząco się opóźniały, utrudniając dotrzymanie terminów. Często jako wygodnej wymówki używano również kwestii braku kompetencji cyfrowych lub słabego połączenia internetowego, czego nie sposób zweryfikować, pracując w konfiguracji międzynarodowej lub między- 
kontynentalnej. Realnym obciążeniem był też stres spowodowany obostrzeniami wprowadzanymi w związku z epidemią oraz duże nagromadzenie aktywności realizowanych w formie zdalnej, co znacznie utrudniało skupienie się uczestników na realizowanych zadaniach. Skutki tego można minimalizować, stosując atrakcyjne wizualnie metody pracy, sformułowane w formie pisemnej zadania i terminy realizacji oraz wielokrotne upewnianie się, że uczestnicy zrozumieli zadania zgodnie z intencją prowadzącego i wiedzą, jak je wykonać.

W tym kontekście warto podjąć refleksję nad sposobem realizacji projektów poświęconych nawiązywaniu relacji między przedstawicielami różnych kultur, wygaszaniu stereotypów i uprzedzeń oraz wzajemnemu poznawaniu się w świecie komunikacji zapośredniczonej przez media. Doświadczenia kolejnych lat i dekad pozwolą stwierdzić, czy wypracowane do tej pory sposoby postępowania, takie jak działania zgodne z hipotezą kontaktu, będą równie skuteczne w nowej rzeczywistości, czy wymagać ona będzie innych rozwiązań dostosowanych do specyfiki komunikacji w nowych realiach.

\section{Bibliografia}

Allport, G. (1954). The Nature of Prejudice. Massachusetts-California-London-Amsterdam-Ontario-Sydney: Addison-Wesley Publishing Company.

Bartel-Radic, A., Lesca, N. (2011). Do intercultural teams need "requisite variety" to be effective? Management international, 15(3), s. 89-118.

Chan, D., K.-S., Cheng, G. (2004). A Comparison of Offline and Online Friendship Qualities at Different Stages of Relationship Development. Journal of Social and Personal Relationships, 21(3), s. 305-320.

Chmielecka, E. (2019). Edukacja dla przyszłości - jak oceniać jej jakość? W: E. Chmielecka, N. Kraśniewska (red.), Edukacja dla przyszłości - jakość kształcenia (s. 13-27). Warszawa: Fundacja Rektorów Polskich.

Dąbrowa E., Markowska-Manista U. (2014). Contacttheory in multiculturalschoolpraxis. W: I. Nowosad (red.), International Forum for Education School Quality and Culture, 1(7), s. 80-100. Toruń: Wydawnictwo Adam Marszałek.

Edukacja międzykulturowa jako element strategii Rady Europy i Unii Europejskiej. (2020). Pobrane z: https://www.researchgate.net/publication/337275754_Edukacja_miedzykulturowa_jako_element_strategii_Rady_Europy_i_Unii_Europejskiej.

Główny Urząd Statystyczny (2013). Narodowy Spis Powszechny Ludności i Mieszkań 2011. Ludność. Stan i struktura demograficzno-społeczna. Warszawa: Zakład Wydawnictw Statystycznych. Pobrane z: http://www.stat.gov.pl.

Januszewska, E., Markowska-Manista, U. (2017). Dziecko „Inne” kulturowo w Polsce. $Z$ badań nad edukacjq szkolnq. Warszawa: Wydawnictwo Akademii Pedagogiki Specjalnej. 
Komisja Europejska. (2020). Erasmus+.Najważniejsze dane liczbowe. Pobrane z: https:// ec.europa.eu/programmes/erasmus-plus/about/key-figures_pl.

Korporowicz, L. (1997). Wielokulturowość a międzykulturowość; od reakcji do in-terakcji. W: M. Kempny, A. Kapciak, S. Łodziński (red.), U progu wielokulturowości. Nowe oblicza społeczeństwa polskiego. Warszawa: Oficyna Wydawnicza.

Lewowicki, T. (2015). Wielokulturowość i globalizacja a strategie edukacji międzykulturowej. Pogranicze. Studia Społeczne, tom XXV, s. 13-24.

Lewicki, C., Michniewicz, M. (2013). Nauczyciel w procesie edukacji wielokulturowej, w wielokulturowości i do wielokulturowości. W: C. Lewicki, M. Cichowska (red.), Wyzwania edukacji wielokulturowej (s. 13-28).

Markowska-Manista, U. (2016). Walka ze stereotypami odmienności kulturowej - szkolne i pozaszkolne pola bitewne. W: M. Dudzikowa, S. Jaskulska (red.). Twierdza. Szkoła w metaforze militarnej. Co w zamian (s. 315-339). Warszawa: Wydawnictwo Wolters Kluwer.

Markowska-Manista, U. (2019). Migrant and Refugee Children in Polish Schools in the Face of Social Transformation. W: C. Maier-Höfer (red.), Die Vielfalt der Kindheit (en) und die Rechte der Kinder in der Gegenwart (s. 79-100), Wiesbaden: Springer VS. DOI: 10.1007/978-3-658-21238-4_4.

Markowska-Manista, U., Zakrzewska-Olędzka, D. (2020b). Rodziny z dziećmi w nowej sytuacji koronawirusa. Raport z badania online. Warszawa: Polskie Stowarzyszenie im. Janusza Korczaka. Pobrane z: https://www.pskorczak.org.pl/strony/pliki_pdf/ raport_covid_19_2020r.pdf.

Markowska-Manista, U., Zakrzewska-Olędzka, D. (2020a). Family with children in times of pandemic - What, Where, How? Dilemmas of adult-imposed prohibitions and orders. Society Register, 4(3), s. 89-110. DOI: 10.14746/sr.2020.4.3.05.

Markowska-Manista, U., Zakrzewska-Olędzka, D. (2017). Pomiędzy teorią i praktyką kontaktu międzykulturowego. Pogranicze. Studia Społeczne, tom XXX, s. 113-129. DOI: $10.15290 /$ pss.2017.30.08.

Mesch, G. (2020). Online and offline relationships. W: Educating 21st Century Children: Emotional Well-being in the Digital Age. Pobrane z: https://www.oecdlibrary.org/ sites/11f6c5b4en/index.html?itemId=/content/component /11f6c5b4-en.

Mesch, G., Talmud, I. (2007). The Quality of Online and Offline Relationships: The Role of Multiplexity and Duration of Social Relationships. The Information Society, 22(3), s. $137-148$.

Nikitorowicz, J. (2017). Tożsamościowe skutki wielokulturowości. Wielość kultur w jednym człowieku czy ekstremizm i separatyzm kulturowy? Lubelski Rocznik Pedagogiczny, t. XXXVI, s. 13-24. DOI: 10.17951/lrp. 2017.36.3.13.

Nikitorowicz, J. (2014). Wielokulturowość - Pogranicze - Człowiek pogranicza. Ku paradygmatowi współistnienia, zachowania i kreowania pokoju. Drohiczyński Przeglq̨d Naukowy. Wielokulturowe Studia Drohiczyńskiego Towarzystwa Naukowego, 6, s. 171-189.

Nikitorowicz, J. (2012). Kultura wiedzy o sobie i innych. W: P. Celiński, J. Hudzik (red.). Kultura wiedzy (s. 111-130). Kraków: Wydawnictwo Uniwersytetu Jagiellońskiego. 
Nikitorowicz, J. (2009). Edukacja regionalna i międzykulturowa. Warszawa: Wydawnictwa Akademickie i Profesjonalne.

Sarzała, S., Piestrzyński, W. (2015). Młodzież i dzieci w cyberprzestrzeni a zagrożenia w sferze socjalizacji. Konińskie Studia Społeczno-Ekonomiczne, 1(2), s. 145-158.

Sasin, M. (2014). Polscy studenci w programie wymiany międzynarodowej „Erasmus” - założenia, stan faktyczny i możliwości zmiany. Dyskursy Młodych Andragogów, 15, s. 75-84.

Sobecki, M. (2014). Komunikacja międzykulturowa w wymiarze religijnym jako wyzwanie edukacyjne. W: J. Nikitorowicz (red.), Od wielokulturowości miejsca do międzykulturowości relacji społecznych. Współczesne strategie kreowania przestrzeni życia jednostki (s. 107-118). Warszawa: Wydawnictwo Akademickie Żak.

Suchocka, A. (2016). Kompetencje międzykulturowe - przywilej czy konieczność? Colloquium Wydziału Nauk Humanistycznych i Społecznych Kwartalnik, 4, s. 121-132.

The World Bank (2016). World Development Report 2016: Digital Dividends. Pobrane z: https://www.worldbank.org/en/publication/wdr2016.

Zakrzewska-Olędzka, D., Markowska-Manista, U. (2019). Intercultural education in a monocultural society - benefits and challenges of the Erasmus+ program students' involvement in the school life. W: ICERI 2019 Proceedings. 12th annual International Conference of Education, Research and Innovation (s. 5521-5526). Seville, Spain: IATED Academy. 